
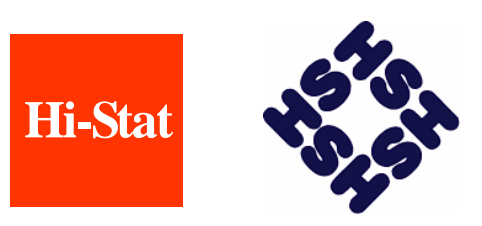

Discussion Paper Series

No.125

\title{
Deposit Insurance and Depositor Discipline: \\ Direct Evidence on Bank Switching Behavior in Japan
}

Noriko Inakura, Satoshi Shimizutani and Ralph Paprzycki

October 2005

Hitotsubashi University Research Unit

for Statistical Analysis in Social Sciences

A 21st-Century COE Program

Institute of Economic Research

Hitotsubashi University

Kunitachi, Tokyo, 186-8603 Japan http://hi-stat.ier.hit-u.ac.jp/ 


\title{
Deposit Insurance and Depositor Discipline: Direct Evidence on Bank Switching Behavior in Japan
}

By

\section{Noriko Inakura, Satoshi Shimizutani and Ralph Paprzycki*}

This version: October, 2005

\begin{abstract}
As Japan's financial system moves toward a more market oriented one, depositor discipline is expected to play a larger role in the monitoring of the country's banks. Relying on detailed survey data on households' bank switching behavior matched with banks' financial data, we examine households' response to bank risk and different deposit insurance schemes. We find that bank switching in response to risk was more frequent in 2001 than in 1996 and that households' choice of bank provides an adequate reflection of banks' financial health. We also examine the determinants of households' knowledge of the deposit insurance scheme and find that income, the amount of households' financial assets, and educational attainment are all significant factors. What is more, households' extent of knowledge regarding the deposit insurance scheme was an important determinant of bank switching behavior. The results suggest that depositor discipline appears to work and could play an important supplementary role in monitoring the banking sector.
\end{abstract}

Key words: depositor discipline, deposit insurance, pay-off, depositor-level data JEL Classification: G21, G32

\footnotetext{
* We would like to thank Naohito Abe, Kazumi Asako, Masahiro Hori, Kaoru Hosono, Tokuo Iwaisako, Satoru Kanoh, and Keiko Murata for their useful comments. The main parts of this project were completed while Inakura and Shimizutani were visiting researchers at the Economic and Social Research Institute at the Economic and Social Research Institute, Cabinet Office. An earlier version of this paper was published as Inakura and Shimizutani (2005) and presented at the Japanese Economic Association Meeting in June. We would also like to thank the Institute of Economic Research, Hitotsubashi University, for providing us with the micro-data from the NEEDS-RADAR Financial Behavior Survey. The views expressed in this paper are our own.

Noriko Inakura: University of Tsukuba; Ph.D candidate, Graduate School of Systems and Information Engineering, University of Tsukuba, 1-1-1, Tennodai, Tsukuba, Ibaraki, Japan, 305-8573; E-mail: ninakura@sk.tsukuba.ac.jp.

Satoshi Shimizutani: (corresponding author): Associate Professor, Institute of Economic Research, Hitotsubashi University, 2-1, Naka, Kunitachi-shi, Tokyo, Japan, 186-8603; Tel 042-580-8369; FAX 042580-8333. E-mail sshimizu@ier.hit-u.ac.jp.

Ralph Paprzycki: Research Fellow, Institute of Economic Research, Hitotsubashi University, 2-1, Naka, Kunitachi-shi, Tokyo, Japan, 186-8603. E-mail: ralphp@ier.hit-u.ac.jp.
} 


\section{Introduction}

A central characteristic of Japan's post-war financial system has been the tight control exercised by the government authorities over financial institutions. Bank monitoring was squarely in the hands of the financial authorities and under the so-called “convoy system," troubled banks would be quietly merged with stronger rivals. Trusting their government to guarantee the safety of their deposits, the public grew indifferent to banks' financial conditions and the potential risk to their savings.

However, financial deregulation begun in the 1980s seriously undermined this system, exposing a series of banking scandals. Financial sector problems further escalated as a result of mounting non-performing loans in the wake of the burst of the bubble economy, culminating in a full-blown banking sector crisis towards the end of the 1990s that saw the collapse of a number of banks and ushered in the end of the “convoy system."

Together with the "big bang" financial sector reforms enacted in the late 1990s, these developments have gradually edged Japan's financial sector toward a system where market discipline is to gradually supplement or replace government monitoring of the banking sector. This shift implies that bank customers play a potentially important role in the monitoring of financial institutions through the discipline they can impose on banks by transferring assets from institutions that are perceived to be risky and inefficient toward those with sound balance sheets and efficient management. In Japan, this mechanism had been largely irrelevant, initially as a result of the "convoy system" that implicitly ruled out the possibility of bank failure, and then, as the financial crisis deepened, the introduction of emergency measures in 1996 that suspended the so-called "pay-off” scheme that capped the amount of deposits covered by the deposit insurance scheme.

However, as the financial sector returned to stability and banks made progress in the disposal of non-performing loans, the government decided, in 2001, to gradually remove the blanket insurance of deposits by partially reinstating the "pay-off" scheme (the cap on the amount of deposits covered by the deposit insurance scheme) on certain types of deposits in 2002. ${ }^{1}$ The Financial Services Agency explicitly states that the aim is to improve the efficiency of the financial sector by forcing depositors to shoulder part of the potential risk (FSA (N.D.)).

\footnotetext{
1 The removal of the full guarantee on bank deposits was subject to substantial political wrangling and, in the event, staggered over several years. While the cap on some types of deposits was reintroduced in 2002, other types of deposits continued to be fully covered until April 2005. For details on the timing of the reinstatement of the "pay-off" scheme for the different types of deposits, see NLI (2004).
} 
Yet, if depositor discipline is indeed to supplement or substitute for government monitoring of the banking sector, depositors must be sufficiently aware and sensitive to the risk of bank failure and respond accordingly to such risk. The aim of this paper is to examine whether this is indeed the case by looking at depositors' bank switching behavior. We do so by taking advantage of a rich and unique set of household-level data from the NEEDS-RADAR Financial Behavior Survey (Kinyu Kodo Chosa) available for the years 1996 and 2001. What makes this survey unique is that it is the only one that provides household-level data which can be matched with data on financial institution. As far as we are aware, ours is the first study to utilize household-level information on bank switching from "old" to "new" banks and combine this with banks' financial data. This integrated data structure allows us to examine what determines depositors' knowledge of the deposit insurance scheme as well as their bank switching behavior and, further, to analyze whether such behavior adequately reflects banks' financial health.

A substantial number of empirical studies have looked at the role of market discipline in the financial sector (Flannery (1998), Demirguc-Kunt and Kane (2002)). They can be divided into two groups according to the methodology adopted. The first focuses on cross-country differences in governmental approaches to bank regulation and supervision in order to examine the effectiveness of market discipline in ensuring banking sector stability (e.g., Barth, Caprio and Levine (2004), Demirguc-Kunt and Huizinga (2004), Hosono, Iwaki and Tsuru (2004)). The second and more common methodology is to utilize data on financial institutions and examine the relationship between changes in the amount of deposits and risk variables (e.g., Goldberg and Hudgins (2002), Park and Peristiani (1998), Maechler and McDill (2003) using U.S. data and Martinez-Peria and Schmukler (2001) using data on Argentina, Chile and Mexico). There are also a number of studies on Japan following this methodology, which provide evidence suggesting that depositor discipline has worked in the case of smaller institutions (Murata and Hori (2004), Hori, Ito and Murata (2005)).

However, these methodologies suffer from a number of shortcomings. First, deposit growth and deposit interest rates, which are frequently used as the dependent variable in such studies, are influenced by bank behavior as well as depositors' behavior and it is often difficult to determine the degree to which deposits are shifted in response to risk perceptions. ${ }^{2}$ Second, bank-switching behavior is non-linear and often related to

\footnotetext{
${ }^{2}$ For example, rather reflecting bank switching behavior in response to risk, a decrease in the amount of deposits may be the result of banks' attempt to improve their capital adequacy ratio to meet BIS standards or household decisions unrelated to changes in financial institutions' riskiness.
} 
the public awareness of risk created by reporting in the news. If this is the case, then a direct examination of household responses to risk is more instructive. And third, household heterogeneity should be taken into account. Switching behavior is likely to be influenced by factors such as household income or assets, educational background, attitudes toward risk, and the regional density of financial institutions. If the government's aim is to strengthen depositor discipline, it would be useful to know what types of households are more sensitive to bank risk and hence likely to transfer deposits to safer institutions.

Our data allow us to investigate these questions. They also allow us to explore the connections between household characteristics, the extent of households' knowledge regarding the deposit insurance scheme, and the likelihood that they would switch banks. Comparing the results of the 1996 and the 2001 survey, our data indicate that, against the backdrop of the crisis in Japan's banking sector during the late 1990s, households became much more aware of the deposit insurance scheme and more sensitive to bank risk. What is more, households responded accordingly by switching banks, and a comparison of households' previous bank and their new bank suggests that such switching behavior is an adequate reflection of banks' financial health.

The remainder of this paper is organized as follows. The next section provides an overview of our data set. Section 3 then examines bank switching behavior in 1996 and 2001 and combines this information with data on banks' financial condition. Section 4 explores what determines depositors' extent of knowledge of the deposit insurance scheme and how this knowledge affects bank switching behavior. The final section summarizes our findings and considers the policy implication.

\section{Description of the Data}

This study takes advantage of the comprehensive household-level data of the NEEDS-RADAR Financial Behavior Survey (Kinyu Kodo Chosa) conducted annually by Nikkei Media Marketing, Inc. The sample consists of randomly chosen households within a 40 kilometer radius of the center of Tokyo with household heads aged between 25 and 69. ${ }^{3}$ The survey is cross-sectional and is based on 5,000 questionnaires sent out annually, providing information on household asset portfolios as well as detailed household demographics. The survey consists of a set of standard questions that are

\footnotetext{
${ }^{3}$ The survey thus includes households from parts of Tokyo, Kanagawa, Chiba and Saitama prefectures. The 2001 survey also covers parts of Ibaraki prefecture.
} 
asked every year and a set of topical questions asked only in certain years.

In this study, we use the surveys conducted in 1996 and 2001 since in both years the survey contains detailed data on household awareness of and responses to changes in the deposit insurance scheme including information on which bank households used. The sample size for 1996 is 2,759 households (response rate: 55.2 percent) and 2,906 households for 2001 (response rate: 58.1 percent). After removing observations for which data necessary for our investigation are not available, the sample size falls to 2,445 households for 1996 and 2,351 for 2001.

Table 1 reports the summary statistics of the main variables for 1996 and 2001. First, we look at household demographics. The average age of the household head in the two survey is about 45 to 47 years and the average annual household income is around 7 million yen. The share of households with detached houses is more than $70 \%$. About $90 \%$ of heads of household are employed. As regards educational attainment, highschool graduates and university graduates each make up about 40 percent. The amount of total financial assets is slightly more than 10 million yen in both years. If we decompose household assets into their components, we see that the amount of time deposits decreased while that of ordinary bank deposits and postal savings deposits increased between 1996 and 2001. This shift is partly explained by the timing of the surveys. The 2001 survey followed the government's decision to reinstate the deposit insurance cap on time deposits in 2002 and households sensitive to bank risk were likely to shift their time deposits to ordinary bank accounts or postal savings accounts, which continued to be fully protected. Lastly, the most popular reason for the choice of a financial institution was the interest rate offered.

We rely on two sources for the bank financial data that we use in Section 4 to match the household survey data with banks' financial condition. The first is Zenkoku Ginko Zaimu Shohyo Bunseki (Analysis of Financial Statements of All Banks) published biannually by the Japanese Bankers Association for all financial institutions except the shinkin banks (credit unions); the second is Zenkoku Shinyo Kinko Zaimu Shohyo (Financial Statements of Shinkin Banks in Japan) by Financial Book Consultants, Ltd. for the credit unions. These two sources readily provide all the financial data we require, such as the liquidity asset ratio, the non-performing loan ratio, etc.

3. Deposit shifting behavior and financial statement of financial institutions

We begin our investigation by examining the bank switching behavior of households 
in 1996 and 2001. In the next step, we then match the information on which banks households withdrew their deposits from and shifted them to with data on the financial condition of those banks in order to explore whether this switching behavior is in accord with the degree of risk associated with each of the financial institutions.

It should be noted that the questions asked in the two surveys were slightly different. In the 1996 survey, respondents were asked whether they were aware of what types of deposits were insured under the deposit insurance scheme. ${ }^{4}$ The second question asked households whether they were considering to switch banks due to concerns regarding the safety of their bank. The third question, finally, asked respondents to indicate the name of the financial institution they used to bank with (we call this their "old” bank) and the name of the bank to which they transferred (were considering to transfer) their deposits (we refer to this as their "new" bank). ${ }^{5}$ This question was also applicable to households which switched banks in response to bank risk even if they were not aware of the deposit insurance scheme.

In contrast, the 2001 survey asked households whether they were aware that the full coverage of time deposits was going to be lifted in April 2002 and the "pay-off” scheme capping the amount of deposits insured at 10 million yen (plus accumulated interest) reinstated. ${ }^{6}$ The second question asked households how they had responded (were planning to respond) to this change, i.e., whether they had switched (or were considering to switch) banks. The third question, finally, was identical to that of the 1996 survey, asking from and to which banks households had transferred (were planning to transfer) their deposits. In both surveys, the names of individual "old" and "new” banks are available for city banks, regional banks, trust banks, bond issuing banks, second-tier regional banks, but not for financial institutions categorized as credit unions, credit cooperatives, labor credit associations, agricultural cooperative, or foreign banks.

Table 2 shows the evidence on bank switching behavior based on these questions. First, we should note that the proportion of households that shifted or were thinking about shifting their deposits to another bank in response to risk increased from 8.6 percent in 1996 to 21.9 percent in 2001. This implies that following the financial crisis

\footnotetext{
${ }^{4}$ It is important to note that although the survey was conducted in the autumn of 1996, the actual survey question still referred to the system in effect before the introduction of the blanked insurance of deposits in the spring of that year.

${ }^{5}$ If households switched deposits from more than one "old" bank to more than one "new" bank (i.e. from bank A to bank B and from bank C to bank D), they were asked to provide information on the transfer involving the largest amount of deposits.

${ }^{6}$ The cap on ordinary deposits was scheduled to be reimposed a year later, in April 2003, but this was subsequently postponed to April 2005.
} 
during the second half of the 1990s, households became more sensitive and responsive to bank risk. If we divide our sample households into those with less and those with more than 10 million yen in financial assets, i.e., the amount corresponding to the deposit insurance cap before the introduction of the emergency measure, we observe a clear difference in switching behavior, with households with financial assets in excess of 10 million yen being considerably more inclined to switch banks in response to risk ${ }^{7}$ In the 1996 survey, the share of households which switched or were considering to switch banks was 13.1 percent for households with more than 10 million yen in financial assets and 5.6 percent for those with less than that amount. In contrast, in the 2001 survey, these shares were 38.3 percent and 9.9 percent, respectively. This result is in line with the expectation that households with financial assets in excess of the deposit insurance cap are more sensitive to bank risk than households whose financial assets fall below this threshold.

We now turn to the pattern in bank switching behavior in terms of what types of financial institutions households turned away from and which they turned to. Looking first at the type of financial institutions that households shifted their deposits to, we find that, in 1996, in more than 80 percent of the cases, the "new bank" was the post office or a city bank, with the former attracting 43.6 percent of those transferring their deposits to another financial institution and the latter attracting 40.3 percent. A similar pattern can be observed in the 2001 survey: 40.9 of those transferring their deposits chose the post office, while 41.7 percent opted for a city bank.

Next, examining which type of financial institutions savers shunned, we find that in both surveys, none of the households switched their deposits away from the post office. Apart from this, however, we find large differences in the 1996 and the 2001 survey in terms of what type of financial institutions fell out of favor. In 1996, about 36 percent of households that moved their assets did so from a city bank and more than 20 percent did so from credit cooperatives. In contrast, in 2001, in about 60 percent of the cases the "old" financial institution was a city bank and the favored destination of deposits withdrawn from city banks were, in roughly equal measure, another city bank or the post office. What is more, using Moody's credit rating, we find that half of the households that switched to another city bank chose the highest-rated, the Bank of Tokyo-Mitsubishi with a "D” credit rating, and another half chose banks with an "E+" rating, while only one household chose a bank with an "E" rating, the lowest on Moody's scale from A to E.

\footnotetext{
${ }^{7}$ To save space, we omit the table showing bank switching behavior categorized by the amount of household financial assets.
} 
In sum, we find that bank switching behavior in response to risk was more frequent in 2001 than in 1996. In more than 80 percent of the cases in which depositors switched banks, the "new" financial institution was a city bank or the post office. And while in 1996, the "old” bank in 21 percent of the cases was a credit union and in 36 percent of the cases a city bank, in 2001, the share of credit unions was only around 10 percent, whereas the share of city banks was almost 60 percent. In other words, by 2001, households had not only become more sensitive to bank risk overall, but also much more discerning with regard to the safety of individual city banks.

Next, we examine the relationship between bank switching behavior and banks' financial condition. Concretely, we test whether significant differences in "old” and “new” banks' financial condition can be observed. If households' choice of bank is based on the perceived risk, then we would expect their "new" bank to be in better financial shape than their "old” bank. We therefore match our information on which banks depositors shifted their assets from and to with indicators of the banks' financial health, using four different indicators. ${ }^{8}$ The first is the liquidity-asset ratio, defined as the share of the sum of cash, deposits and government bonds in total assets. A financial institution with a higher share of liquid assets is in a better position to cope with large amounts of withdrawals and is therefore healthier. The second indicator is the operating profit ratio, defined as the operating profit divided by total assets. The third indicator is the nonperforming loan ratio, defined as the amount of risk-adjusted nonperforming loans out of total loans, ${ }^{9}$ while the fourth is the capital-asset ratio. ${ }^{10}$

Furthermore, we compare the growth and amount of deposits and the amount of total assets. If depositors are sensitive to risk and switch banks, then we would expect deposits at the "new" banks to grow faster than those at the "old” banks. If this is indeed the case, our findings would be consistent with preceding studies which found a negative correlation between bank risk and deposit growth. We should also note that larger financial institutions (i.e., those with a larger deposit base) are not necessarily

\footnotetext{
${ }^{8}$ These indicators are the same as those employed by Murata and Hori (2004).

${ }^{9}$ Risk-adjusted loans are officially defined as the sum of loans to legally bankrupt borrowers, loans in arrears by 6 months or more, loans in arrears by 3 to 6 months, and restructured loans. Data on riskadjusted loans are not publicly available and we need to estimate these figures. Due to a lack of all the necessary data, risk-adjusted loans for 1995 and 1996 are calculated as the sum of loans to legally bankrupt borrowers and loans in arrears by 6 months or more.

${ }^{10}$ In this analysis, all except one of the shinkin banks are excluded because they cannot be identified. Also excluded are credit cooperatives, labor credit associations as well as several types of financial institutions which do not fall under the deposit insurance scheme, such as foreign banks, agricultural cooperatives, securities companies, life-insurance companies and Japan Post. To protect deposits, agricultural co-ops have to join the Agricultural and Fishery Cooperative Savings Insurance Corporation, securities companies are members of the Investor Protection Fund, and life-insurance companies join the Life Insurance Policyholders Protection Corporation of Japan.
} 
healthier. Therefore, if we find that customers' new banks are both significantly larger and in better financial shape, we can unequivocally say that depositors are sensitive to banks' financial health and switch their deposits accordingly. If, however, depositors switch their savings to larger banks, but no significant difference in "old" and "new" banks' financial health is observed, this would indicate that depositors believe that certain banks are "too big to fail."

Table 3 tests the significance in the means of above-mentioned financial indicators and deposit growth. Because the survey does not allow us to determine when households switched banks, we proceed by comparing the data for households' "old" and "new" bank both in 1995 and in 1996, where the labels "old" and "new" are based on the information of the 1996 survey. ${ }^{11}$ Doing so, we find that "new" banks have higher capital asset ratios, larger amounts of total assets and lower non-performing loan ratios. In other words, "new” banks, i.e., banks that households switch their deposits to, are financially sounder and have larger assets. The differences in these indicators are statistically significant.

Next, comparing these indicators for the years 2000 and 2001 and using information on households" "old” and “new" banks based on the 2001 survey, we observe that customers' new banks have significantly higher ratios of liquid assets, higher capital asset ratios and larger amounts of total assets. In other words, customers' new banks are financially healthier and are larger in terms of their financial assets. Reflecting the fact that the cap on time deposits was to be reintroduced in April 2002, we also observe that time deposits at "old" banks shrank significantly faster than those at "new" banks. On the other hand, the difference in the growth of ordinary deposits is not significant.

In sum, we find that households' "new" banks - banks to which they switched their deposits - were significantly healthier in terms of their liquidity and capital asset ratios, had greater amounts of total assets, and experienced a greater increase in total deposits and a smaller contraction in time deposits. Our findings on household bank switching behavior thus confirm preceding studies on the role of banks' financial health and deposit growth. In the next section, we examine the determinants of bank switching by looking at household characteristics.

\section{Households' knowledge of the deposit insurance scheme and bank switching}

\footnotetext{
11 Concretely, the averages for "old" and "new" banks were calculated as follows: Using the information on households' "old” and "new" banks, e.g., Household 1: OLD=A, NEW=B; Household 2: OLD=D, $\mathrm{NEW}=\mathrm{A}$; Household 3: OLD=C, NEW=A, the average values for "old" banks consist of the financial data for A, D, and C, while that of the "new" banks consist of the data for B, A, and A.
} 
This section explores what determines households' knowledge of the deposit insurance scheme and bank switching behavior. In contrast with the analyses in the previous section, we also include households in our analysis which did not switch banks.

First, we examine households' extent of knowledge regarding the deposit insurance scheme. The 1996 survey asked respondents whether they knew which types of deposits were protected under the deposit insurance scheme, while the 2001 survey asked households whether they knew about the reintroduction of the cap on certain types of deposits. Table 4 provides the results of the two surveys. The results of the 1996 survey show that only 7 percent of households knew the detailed contents of the deposit insurance scheme, but more than a half at least knew of the scheme. In contrast, the 2001 survey shows that a quarter of households had detailed knowledge of the reintroduction of the deposit insurance cap, its timing and the types of deposits concerned, while about 70 percent at least knew that a cap of some kind was to be reimposed. Although the questions differed in the two surveys, we may conclude that depositors were more aware of the deposit insurance scheme after the financial crisis in the late 1990s. Moreover, households with better knowledge of the deposit insurance scheme were more inclined to switch banks. The share of households in 1996 that were well informed about the deposit insurance scheme and switched banks was 16 percent, while in 2001 that figure increased to 48 percent. In other words, the share of households with better knowledge increased between 1996 and 2001 and the share among these that switched banks also increased.

Next, we employ an ordered probit model to explore the determinants of knowledge of the deposit insurance scheme. The specification is as follows:

$Y_{i}=\alpha+\beta_{1} X_{1 i}+\beta_{2} X_{2 i}+\beta_{3} X_{3 i}+\beta_{4} X_{4 i}+\beta_{5} X_{5 i}+\beta_{6} X_{6 i}+\varepsilon_{i}$

where $i$ denotes the $i$ th household.

$Y_{i}=2$ if a household had detailed knowledge of the deposit insurance scheme (in the 1996 survey, those who knew which types of deposits were covered by the deposit insurance scheme and, in the 2001 survey, those who knew when the deposit insurance cap was to be reintroduced and what types of deposits were affected);

$Y_{i}=1$ if a household knew of the deposit insurance scheme in the 1996 survey or the of the reintroduction of the deposit insurance cap in the 2001 survey;

$Y_{i}=0$ if a household did not know about deposit insurance scheme in the 1996 survey or 
about the reintroduction of the deposit insurance cap in the 2001 survey;

$X_{1}$ : quadratic age of the household head;

$X_{2}$ : tenancy status (detached house owner $=1$ );

$X_{3}$ : employment status of the household head (employed=1);

$X_{4}$ : educational attainment of the household head;

$X_{5}$ : annual household income;

$X_{6}$ : total amount of household financial assets; and

$\varepsilon_{i}$ : well-behaved error term.

Table 5 reports the estimation results based on the specification above. Both in the regression for 1996 and that for 2001, we find that the coefficients on income, educational attainment and the total amount of household financial assets are positive and significant. In addition, the coefficients on the age of the head of household, the dummy for households owning a detached house, and the dummy for being employed are also positive and significant. These results suggest that households with a higher level of income, greater financial assets and higher educational attainment were more knowledgeable regarding the deposit insurance scheme or the reintroduction of the deposit insurance cap.

Further, we investigate whether households' knowledge regarding the deposit insurance scheme or the reintroduction of the deposit insurance cap were more likely to switch banks than households that knew little or nothing about these schemes. We again employ an ordered probit model:

$$
\begin{aligned}
& Z_{i}=\alpha+\beta_{1} X_{1 i}+\beta_{2} X_{2 i}+\beta_{3} X_{3 i}+\beta_{4} X_{4 i}+\beta_{5} X_{5 i}+\beta_{51 i}\left(X_{51 i} * X_{5 i}\right) \\
& +\beta_{52 i}\left(X_{52 i} * X_{5 i}\right)+\beta_{61} X_{61 i}+\beta_{62} X_{62 i}+\beta_{7} X_{7 i}+\varepsilon_{i}
\end{aligned}
$$

where $i$ denotes the ith household.

$Z_{i}=2$ if a household actually switched banks in response to risk;

$Z_{i}=1$ if a household was considering to switch banks in response to risk; and

$Z_{i}=0$ if a household did not consider it necessary to switch banks. ${ }^{12}$

In addition to the explanatory variables already employed in (1), we use $X_{51}$ : if a household has ordinary deposits in excess of 10 million yen; $X_{52}$ : if a household has time deposits in excess of 10 million yen; $X_{61}$ : if a household has detailed knowledge of the deposit insurance scheme (in the 1996

\footnotetext{
${ }^{12}$ In contrast with the 1996 survey, the 2001 survey also offered respondents the option to answer they were "uncertain" whether they would switch banks. We removed households that chose this answer from the sample used for this regression.
} 
survey, those who knew which types of deposits were covered by the deposit insurance scheme and, in the 2001 survey, those who knew when the deposit insurance cap was to be reintroduced and what types of deposits were affected);

$X_{62}$ : if a household did not know about the deposit insurance scheme in the 1996 survey or about the reintroduction of the deposit insurance cap in the 2001 survey; and

$X_{7}$ : households' reason for choosing a particular financial institution. ${ }^{13}$

Table 6(a) reports the results for this specification based on the 1996 survey and Table 6(b) those based on the 2001 survey. We observe some interesting results. First, the "knowledge" dummy had some effect on bank switching behavior. Table 6(a) shows that households that did not know about the deposit insurance scheme in 1996 were less likely to consider it necessary to switch banks. In the 2001 survey, households with detailed knowledge of the reinstatement of the deposit insurance cap were more likely to consider it necessary to switch banks (Table 6(b)). Second, the results both for 1996 and for 2001 indicate that the larger a household's financial assets, the more likely it was to switch or to consider it necessary to switch banks. Third, in 2001, households with time deposits in excess of 10 million yen saw it especially necessary to switch banks, as indicated by the large and significant coefficient on this variable. Fourth, we notice that the interaction term for total household assets and the dummy variable for ordinary deposits in excess of 10 million yen is not significant while the interaction term with time deposits in excess of 10 million yen is positive and significant for households that switched or were considering to switch banks. This result suggests that households' bank switching behavior closely responds to changes in the deposit insurance scheme: As is only to be expected, households with larger financial assets are more inclined to switch banks; but we also find that households with large ordinary deposits, which continued to be fully insured until 2005, did not find it necessary to switch banks, while those with large time deposits, on which the cap was reinstated in 2002, did. In other words, the reintroduction of the "pay-off" scheme stimulated switching behavior as desired. Finally, most of the other coefficients are not statistically significant.

\footnotetext{
${ }^{13}$ We include this variable since some households are not able to switch banks simply because there are no alternatives in their vicinity. We also tried to incorporate dummy variables for households' "old” banks (city banks, regional banks, Japan Post and others) to control for bank switching behavior since households that have deposits with risky banks are more inclined to shift their deposits. Our dataset contains information on each households" "main bank" but we cannot discern whether this information refers to households" "old” or "new” bank.
} 
In sum, our results show that households with higher levels of income, larger financial assets and higher educational attainment tend to be more knowledgeable with regard to the deposit insurance scheme or the reinstatement of the "pay-off" scheme. In addition, households with knowledge about the deposit insurance scheme and/or larger financial assets are more likely to switch banks.

\section{Conclusion}

Taking advantage of a comprehensive set of household-level data, this study analyzed bank switching behavior in Japan in 1996 and 2001. We explored whether such switching behavior was an adequate reflection of banks' financial health. We also examined what determined households' knowledge of the deposit insurance scheme.

We found that bank switching behavior in response to risk was more frequent in 2001 than in 1996. In both surveys, in more than 80 percent of the cases where households switched banks, the "new" financial institution was a city bank or the post office. But while in 1996 the "old” bank was a city bank in only 36 percent of the cases, in 2001 this figure jumped to almost 60 percent, suggesting that households had become much more discerning with regard to the safety of individual city banks.

This bank switching behavior is in line with banks' financial health at the time: Banks to which households switched their deposits tended to be in a better financial condition than households' "old” bank. We also found that households with higher incomes, larger assets, and higher educational attainment were more informed regarding the deposit insurance scheme and this better awareness led households with larger financial assets to switch banks in 2001.

Our findings contain some important policy implications. First, comparing the results between the 1996 and 2001 surveys, we clearly observe that depositors were more sensitive to bank risk in 2001. Households' bank switching behavior was closely correlated with banks' financial health and size. In other words, households do "punish" weak banks by withdrawing assets and switching them to safer banks.

The financial sector crisis of the 1990s has clearly exposed the shortcomings of Japan's traditional approach to supervising the financial sector by relying on the government alone. The findings of this paper suggest that depositors can potentially play an important supplementary role in monitoring banks' performance. Now that full coverage has been lifted and all types of deposits are once again subject to the "pay-off" cap, an important next step in strengthening the role of market forces would be to improve the transparency of banks' financial accounts. 


\section{References}

Barth, James R., Gerard Caprio Jr., and Ross Levine (2004). “Bank Regulation and Supervision: What Works Best?” Journal of Financial Intermediation, 13, 205-248.

Demirguc-Kunt, Asli and Edward J. Kane (2002). “Deposit Insurance Around the Globe: Where Does It Work?” Journal of Economic Perspectives, 16, 175-195.

Demirguc-Kunt, Asli and Harry Huizinga (2004). “Market Discipline and Deposit Insurance.” Journal of Monetary Economics 51, 375-399.

Financial Services Agency (FSA) (N.D.). “Frequently Asked Questions; Bank and Other Financial Institutions; Pay-off (Reimbursement of Deposits).” Online: $<$ http://www.fsa.go.jp/qanda/faq.html $>$.

Flannery, Mark J. (1998). “Using Market Information in Prudential Bank Supervision:

A Review of the U.S. Empirical Evidence.” Journal of Money, Credit and Banking, 30, 273-305.

Goldberg, G. Lawrence and Sylvia C. Hudgins (2002). “Depositor Discipline and Changing Strategies for Regulating Thrift Institutions.” Journal of Financial Economics, 63, 263-274.

Hori, Masahiro, Yasuaki Ito and Keiko Murata (2005). “Do Depositors Respond to Bank Risks as Expected? Evidence from Japanese Financial Institutions in the 
Banking Crisis.” ESRI Discussion Paper Series, 151, Economic and Social Research Institute, Cabinet Office.

Hosono, Kaoru, Hiroko Iwaki and Kotaro Tsuru (2004). “Bank Regulation and Market Discipline Around the World.” RIETI Discussion Paper Series 04-E-031, Research Institute of Economy, Trade and Industry.

Inakura, Noriko and Satoshi Shimizutani (2005). "Yokin Hoken Seido, Pay-off Kaikin to Yokinsha Kiritsu: Kakei no Micro Data ni yoru Azukekae Kodo no Kensho [The Deposit Insurance System, the Reinstatement of the Pay-off Scheme and Depositor Discipline: An Analysis of Bank Switching Behavior Based on Household Data],” Hi-Stat Discussion Paper Series, 83, Institute of Economic Research, Hitotsubashi University. Online:

< $\underline{\text { http://hi-stat.ier.hit-u.ac.jp/research/discussion/2005/083.html }>\text {. }}$

Kiser, Elizabeth K. (2002). "Household Switching Behavior at Depository Institutions:

Evidence from Survey Data.” Finance and Economics Discussion Series, 2002-44, Board of Governors of the Federal Reserve System.

Maechler, Andrea and Kathleen M. McDill (2003). “Dynamic Depositor Discipline in U.S. banks.” IMF Working Papers 03/226, International Monetary Fund. Martinez-Peria, Maria Soledad and Sergio L. Schmukler (2001). “Do Depositors Punish 
Banks for Bad Behavior? Market Discipline, Deposit Insurance, and Banking Crises.” Journal of Finance, 56, 1029-1051.

Moody’s Kakuzuke Geppo [Moody's Japanese Ratings Guide] (December 2001) Tokyo:

Moody’s Japan,

Murata, Keiko and Masahiro Hori (2004). "End of the Convoy System and the Surge of Market Discipline: Evidence from Japanese Small Financial Institutions.” ESRI Discussion Paper Series, 105, Economic and Social Research Institute, Cabinet Office.

NLI Research Institute (2004). “On the Introduction of the Deposit Insurance Cap for Demand Deposits in 2005”. Online: < $\underline{\text { http://www.nli- }}$ research.co.jp/eng/resea/econo/eco040517.pdf> (accessed 20 October 2005).

Park, Sangkyun and Stavros Peristiani (1998). "Market Discipline by Thrift Depositors.” Journal of Money, Credit and Banking 30, 347-364. 
Table 1: Descriptive statistics

\begin{tabular}{|c|c|c|c|c|}
\hline & \multicolumn{2}{|c|}{1996} & \multicolumn{2}{|c|}{2001} \\
\hline & Mean & $\begin{array}{c}\text { Std. } \\
\text { deviation }\end{array}$ & Mean & $\begin{array}{c}\text { Std. } \\
\text { deviation }\end{array}$ \\
\hline \multicolumn{5}{|l|}{ Knowledge of the deposit insurance scheme } \\
\hline Knowledge level 2 (detailed knowledge) & 0.07 & 0.25 & 0.25 & 0.43 \\
\hline Knowledge level 1 (basic knowledge) & 0.46 & 0.50 & 0.43 & 0.50 \\
\hline Knowledge level 0 (no knowledge) & 0.48 & 0.50 & 0.32 & 0.47 \\
\hline \multicolumn{5}{|l|}{ Bank switching behavior } \\
\hline Actually switched & 0.03 & 0.18 & 0.04 & 0.20 \\
\hline Considering to switch & 0.07 & 0.26 & 0.27 & 0.45 \\
\hline Not considering it necessary to switch & 0.89 & 0.31 & 0.42 & 0.49 \\
\hline Other & & & 0.27 & 0.44 \\
\hline Age of household head & 45.18 & 12.40 & 46.78 & 13.51 \\
\hline Annual income (hundred thousand yen) & 71.95 & 46.91 & 67.81 & 48.03 \\
\hline Detached house owner & 0.68 & 0.47 & 0.77 & 0.42 \\
\hline Employed (household head) & 0.92 & 0.27 & 0.87 & 0.34 \\
\hline \multicolumn{5}{|l|}{ Educational attainment (household head) } \\
\hline Junior high school & 0.10 & 0.30 & 0.09 & 0.29 \\
\hline High school & 0.38 & 0.49 & 0.36 & 0.48 \\
\hline Junior college & 0.10 & 0.30 & 0.11 & 0.31 \\
\hline University / Grad school & 0.41 & 0.49 & 0.44 & 0.50 \\
\hline \multicolumn{5}{|l|}{ Financial assets (hundred thousand yen) } \\
\hline Ordinary deposits & 9.72 & 25.71 & 14.82 & 29.60 \\
\hline Time deposits & 42.13 & 120.97 & 33.57 & 82.04 \\
\hline Postal savings & 19.79 & 39.84 & 24.01 & 43.40 \\
\hline Other & 28.50 & 69.34 & 30.45 & 84.64 \\
\hline Total financial assets & 100.14 & 185.48 & 102.86 & 165.78 \\
\hline \multicolumn{5}{|c|}{ The most important reason for choosing a financial institution } \\
\hline Interest rate & 0.51 & 0.50 & 0.40 & 0.49 \\
\hline Location, number and opening hours of branches & 0.22 & 0.41 & 0.23 & 0.42 \\
\hline Service contents & 0.14 & 0.35 & 0.19 & 0.39 \\
\hline Financial condition & 0.13 & 0.33 & 0.18 & 0.38 \\
\hline \multicolumn{5}{|l|}{ Area of residence } \\
\hline Central Tokyo (23 wards) & 0.26 & 0.44 & 0.28 & 0.45 \\
\hline Outer Tokyo & 0.12 & 0.33 & 0.14 & 0.35 \\
\hline Saitama prefecture & 0.19 & 0.39 & 0.17 & 0.38 \\
\hline Chiba prefecture & 0.16 & 0.37 & 0.17 & 0.38 \\
\hline Kanagawa prefecture & 0.26 & 0.44 & 0.23 & 0.42 \\
\hline Ibaraki prefecture & - & - & 0.01 & 0.10 \\
\hline Number of observations & \multicolumn{2}{|c|}{2445} & \multicolumn{2}{|c|}{2351} \\
\hline
\end{tabular}

Note: Definitions of the different knowledge levels are provided in Table 3. 
Table 2(a): Bank switching behavior (1996)

\begin{tabular}{|c|c|c|c|c|c|c|c|c|c|c|}
\hline Old & City banks & $\begin{array}{l}\text { Regional } \\
\text { banks }\end{array}$ & Trust banks & $\begin{array}{l}\text { Bond } \\
\text { issuing } \\
\text { banks }\end{array}$ & $\begin{array}{l}\text { Second-tier } \\
\text { regional } \\
\text { banks }\end{array}$ & $\begin{array}{l}\text { Credit } \\
\text { unions }\end{array}$ & $\begin{array}{l}\text { Small and } \\
\text { medium } \\
\text { banks }\end{array}$ & Post office & $\begin{array}{l}\text { Security } \\
\text { companies }\end{array}$ & \begin{tabular}{|l} 
Total of \\
"old" banks
\end{tabular} \\
\hline City banks & 36 & 2 & & & 1 & 5 & 1 & 28 & 2 & 75 \\
\hline Regional banks & 6 & & & & & 1 & & 12 & & 19 \\
\hline Trust banks & 8 & & 2 & & & 1 & & 14 & 1 & 26 \\
\hline Bond issuing banks & 2 & & 2 & 1 & & & & 1 & 1 & 7 \\
\hline Second-tier regional bant & 12 & & 1 & & & 3 & & 4 & & 20 \\
\hline Credit unions & 19 & 4 & & & & 2 & 1 & 17 & 1 & 44 \\
\hline Small and medium banks & 9 & 1 & & & & 1 & & 9 & & 20 \\
\hline \begin{tabular}{|l|} 
Post office \\
\end{tabular} & & & & & & & & & & 0 \\
\hline Total of "new" banks & 92 & 7 & 5 & 1 & 1 & 13 & 2 & 85 & 5 & 211 \\
\hline
\end{tabular}

Note: 1. Figures in cross-tabulation table indicate numbers of households.

2. "Medium-Small Banks" include credit cooperatives, laborers' credit cooperatives and agricultural co-ops.

Table 2(b): Bank switching behavior 2001)

\begin{tabular}{|c|c|c|c|c|c|c|c|c|c|c|c|c|c|c|c|c|}
\hline \multirow{2}{*}{ Old } & \multirow{2}{*}{ New } & \multicolumn{5}{|c|}{ City banks } & \multirow{2}{*}{$\begin{array}{l}\text { Regional } \\
\text { banks }\end{array}$} & \multirow{2}{*}{$\begin{array}{l}\text { Trust } \\
\text { banks }\end{array}$} & \multirow{2}{*}{$\begin{array}{l}\text { Second- } \\
\text { tier } \\
\text { regional } \\
\text { banks }\end{array}$} & \multirow{2}{*}{$\begin{array}{l}\text { Credit } \\
\text { unions }\end{array}$} & \multirow{2}{*}{$\begin{array}{l}\text { Small and } \\
\text { medium } \\
\text { banks }\end{array}$} & \multirow{2}{*}{$\begin{array}{l}\text { Foreign } \\
\text { banks }\end{array}$} & \multirow{2}{*}{$\begin{array}{l}\text { Internet } \\
\text { banks }\end{array}$} & \multirow{2}{*}{ Post office } & \multirow{2}{*}{$\begin{array}{l}\text { Securities/ } \\
\text { Life- } \\
\text { insurance } \\
\text { companies }\end{array}$} & \multirow{2}{*}{$\begin{array}{l}\text { Total of } \\
\text { "old" banks }\end{array}$} \\
\hline & & "D" rating & "E+" rating & "E" rating & Unknown & Total & & & & & & & & & & \\
\hline \multirow{4}{*}{ City banks } & " D" rating & 2 & 10 & 1 & 1 & 14 & 3 & & 1 & & & 1 & 2 & 16 & 1 & 38 \\
\hline & " E+" rating & 48 & 43 & & & 91 & 9 & 1 & 1 & 3 & 2 & 7 & 3 & 84 & 4 & 205 \\
\hline & "E" rating & 15 & 16 & & & 31 & & 2 & & 2 & 1 & 1 & & 23 & 3 & 63 \\
\hline & Total & 65 & 69 & 1 & 1 & 136 & 12 & 3 & 2 & 5 & 3 & 9 & 5 & 123 & 8 & 306 \\
\hline \multicolumn{2}{|c|}{ Regional banks } & 17 & 11 & 3 & & 31 & & 2 & 2 & 3 & 2 & 1 & & 36 & 3 & 80 \\
\hline \multicolumn{2}{|c|}{ Bond issuing banks } & & 3 & & & 3 & & 1 & & & & & & 2 & 2 & 8 \\
\hline \multicolumn{2}{|c|}{ Second-tier regional banks } & 6 & 2 & & 1 & 9 & 2 & 1 & & 1 & 2 & & & 9 & 1 & 25 \\
\hline \multicolumn{2}{|c|}{ Credit unions } & 11 & 10 & 1 & & 22 & 2 & 1 & 1 & 2 & & & & 24 & 1 & 53 \\
\hline \multicolumn{2}{|c|}{ Small and medium banks } & 1 & 2 & & & 3 & & & & 1 & & & & 4 & & 8 \\
\hline \multicolumn{2}{|c|}{ Foreign banks } & & & & & & & & & & & & & 1 & & 1 \\
\hline \multicolumn{2}{|c|}{\begin{tabular}{|l|} 
Postal Savings \\
\end{tabular}} & & & & & & & & & & & & & & & 0 \\
\hline \multicolumn{2}{|c|}{ Total of "new" banks } & 105 & 102 & 6 & 2 & 215 & 18 & 14 & 5 & 12 & 8 & 11 & 5 & 211 & 17 & 516 \\
\hline
\end{tabular}

Note: The ratings for the city banks, obtained from Moody's Kakuzuke Geppo [Moody's Japanese Ratings Guide] (December 2001), are as follows:

D Bank of Tokyo-Mitsubishi.

E+ Sanwa Bank, Dai-Ichi Kangyo Bank, Tokai Bank, Fuji Bank, Sumitomo Mitsui Banking Corporation.

E Asahi Bank, Daiwa Bank. 
Table 3: Test of differences in "old" and "new" banks' financial condition

\begin{tabular}{|c|c|c|c|c|c|c|c|}
\hline & \multicolumn{4}{|c|}{ FY 1995} & \multicolumn{3}{|c|}{ FY 1996} \\
\hline & Old & New & & $\begin{array}{c}\text { No. of } \\
\text { observations }\end{array}$ & Old & New & $\begin{array}{c}\text { No. of } \\
\text { observations }\end{array}$ \\
\hline Total assets (trillion yen) & 24.977 & 51.905 & $* * *$ & 61 & 23.429 & $53.073 * * *$ & 65 \\
\hline Liquidity-asset ratio (\%) & 12.309 & 14.246 & & 61 & 9.769 & $12.921 * * *$ & 65 \\
\hline Operating profit ratio (\%) & 0.726 & 0.857 & $* * *$ & 61 & 0.679 & 0.768 & 63 \\
\hline Nonperforming loan ratio (\%) & 4.596 & 2.590 & $* * *$ & 59 & 4.604 & $2.611 * * *$ & 65 \\
\hline \multirow[t]{3}{*}{ Capital-asset ratio (\%) } & 8.376 & 9.217 & $* * *$ & 61 & 8.172 & $8.989 * * *$ & 65 \\
\hline & \multicolumn{4}{|c|}{ FY 2000} & \multicolumn{3}{|c|}{ FY 2001} \\
\hline & Old & New & & $\begin{array}{c}\text { No. of } \\
\text { observations }\end{array}$ & Old & New & $\begin{array}{c}\text { No. of } \\
\text { observations }\end{array}$ \\
\hline Total assets (trillion yen) & 46.166 & 66.464 & $* * *$ & 178 & 42.385 & $62.072 * * *$ & 178 \\
\hline Liquidity-asset ratio (\%) & 13.054 & 16.049 & $* * *$ & 178 & 15.190 & $16.316^{* * *}$ & 178 \\
\hline Operating profit ratio (\%) & 0.675 & 0.529 & $* * *$ & 178 & 0.657 & 0.627 & 178 \\
\hline Nonperforming loan ratio (\%) & 6.653 & 7.193 & & 178 & 8.530 & 8.320 & 178 \\
\hline \multirow[t]{2}{*}{ Capital-asset ratio (\%) } & 11.234 & 11.356 & * & 177 & 10.326 & $10.512 * *$ & 178 \\
\hline & \multicolumn{4}{|c|}{ FY1995-FY1996 } & \multicolumn{3}{|c|}{ FY2000-FY2001 } \\
\hline Growth rate of all deposits & -1.908 & 2.615 & $* *$ & 59 & 3.693 & $6.193 * * *$ & 178 \\
\hline Growth rate of ordinary deposits & 0.123 & 3.680 & $* * *$ & 59 & 57.861 & 56.362 & 178 \\
\hline Growth rate of time deposits & 2.677 & 0.701 & & 59 & -18.533 & $-16.482 * *$ & 178 \\
\hline
\end{tabular}

Notes: 1 . Households which did not indicate their "old" and/or "new" bank were removed from the sample.

2. $* * *, * *$ and $*$ denote that the null hypothesis that the difference between two sample means is equal to zero is rejected at the 1,5 and $10 \%$ level of significance, respectively. 


\begin{tabular}{|c|c|c|c|c|}
\hline \multicolumn{5}{|c|}{ Table 4(a): Households' knowledge regarding the deposit insurance scheme and bank switching behavior (1996) } \\
\hline & Switched banks & $\begin{array}{c}\text { Were } \\
\text { considering to } \\
\text { switch hanks }\end{array}$ & $\begin{array}{l}\text { Did not consider } \\
\text { it necessary to } \\
\text { switch hanks }\end{array}$ & Total \\
\hline [Knowledge $=2$ ] Had detailed knowledge of the insurance scheme & 10 & 17 & 137 & 164 \\
\hline$[$ Knowledge $=1]$ Knew of the deposit insurance scheme & 45 & 94 & 980 & 1119 \\
\hline [Knowledge $=0$ ] Did not know about the deposit insurance scheme & & 68 & 1072 & 1170 \\
\hline Total & 85 & 179 & 2189 & 2453 \\
\hline
\end{tabular}

Note: Figures in the cross-tabulation table indicate the number of households.

Table 4(b): Households' knowledge regarding the reintroduction of the deposit insurance cap and bank switching behavior (2001)

\begin{tabular}{|c|c|c|c|c|c|}
\hline & Switched banks & $\begin{array}{c}\text { were } \\
\text { considering to } \\
\text { switch hanks }\end{array}$ & $\begin{array}{l}\text { Did not consider } \\
\text { it necessary to } \\
\text { switch hanks }\end{array}$ & Others & Total \\
\hline [Knowledge $=2$ ] Had detailed knowledge of the reintroduction of the deposit insurance caf & 53 & 236 & 286 & 23 & 598 \\
\hline [Knowledge $=1$ ] Knew of the reintroduction of the deposit insurance cap & 39 & 343 & 531 & 147 & 1060 \\
\hline [Knowledge $=0$ ] Did not know about the reintroduction of the deposit insurance cap & 6 & 84 & 210 & 507 & 807 \\
\hline Total & 98 & 663 & 1027 & 677 & 2465 \\
\hline
\end{tabular}

Note: Figures in the cross-tabulation table indicate the number of households. 
Table 5(a): Determinants of knowledge of the deposit insurance scheme (1996)

\begin{tabular}{|c|c|c|c|c|c|c|c|c|c|}
\hline & \multicolumn{3}{|c|}{ Knowledge $=2$} & \multicolumn{3}{|c|}{ Knowledge=1 } & \multicolumn{3}{|c|}{ Knowledge $=0$} \\
\hline & $\begin{array}{c}\text { Marginal } \\
\text { effect }\end{array}$ & Std. error & & $\begin{array}{c}\text { Marginal } \\
\text { effect }\end{array}$ & Std. error & & $\begin{array}{c}\text { Marginal } \\
\text { effect }\end{array}$ & Std. error & \\
\hline Age (household head) & 0.0000 & 0.0023 & & -0.0001 & 0.0046 & & 0.0001 & 0.0064 & \\
\hline $\mathrm{Age}^{2}$ & 0.0000 & 0.0000 & & 0.0000 & 0.0001 & & 0.0000 & 0.0001 & \\
\hline Annual income (million yen) & 0.0028 & 0.0009 & $* * *$ & 0.0061 & 0.0017 & $* * *$ & -0.0089 & 0.0022 & $* * *$ \\
\hline Detached house owner & 0.0073 & 0.0075 & & 0.0156 & 0.0151 & & -0.0228 & 0.0209 & \\
\hline Employed (household head) & -0.0179 & 0.0142 & & -0.0384 & 0.0288 & & 0.0563 & 0.0397 & \\
\hline \multicolumn{10}{|c|}{ Educational attainment (household head) } \\
\hline Junior high school & -0.0401 & 0.0133 & $* * *$ & -0.0860 & 0.0251 & $* * *$ & 0.1261 & 0.0338 & $* * *$ \\
\hline Junior college & -0.0005 & 0.0119 & & -0.0010 & 0.0241 & & 0.0014 & 0.0336 & \\
\hline University / Grad school & 0.0297 & 0.0088 & $* * *$ & 0.0636 & 0.0163 & $* * *$ & -0.0932 & 0.0213 & $* * *$ \\
\hline Total financial assets (million yen) & 0.0008 & 0.0002 & $* * *$ & 0.0018 & 0.0003 & $* * *$ & -0.0026 & 0.0004 & $* * *$ \\
\hline
\end{tabular}

Number of observations $=2445$

McFadden's pseudo $\mathrm{R}^{2}=0.045$

Note: 1 . We employed an order probit model. ***,** and $*$ denote that the null hypothesis that the estimated marginal effect is equal to zero is rejected at the 1,5 and $10 \%$ level of significance, respectively.

2. The base case for educational attainment is "high school" and that for area of residence is Central Tokyo (23 wards). The coefficients on the area of residence were insignificant and are omitted from this table to conserve space.

Table 5-2: Determinants of knowledge of the reinstatement of the deposit insurance cap (2001)

\begin{tabular}{|c|c|c|c|c|c|c|c|c|}
\hline & \multicolumn{3}{|c|}{ Knowledge $=2$} & \multicolumn{2}{|c|}{ Knowledge $=1$} & \multicolumn{3}{|c|}{ Knowledge $=0$} \\
\hline & $\begin{array}{c}\text { Marginal } \\
\text { effect }\end{array}$ & Std. error & & $\begin{array}{c}\text { Marginal } \\
\text { effect }\end{array}$ & Std. error & $\begin{array}{c}\text { Marginal } \\
\text { effect }\end{array}$ & Std. error & \\
\hline Age (household head) & 0.0093 & 0.0042 & $* *$ & 0.0017 & 0.0026 & -0.0110 & 0.0048 & $* *$ \\
\hline $\operatorname{Age}^{2}$ & -0.0001 & 0.0000 & $*$ & 0.0000 & 0.0000 & 0.0001 & 0.0001 & * \\
\hline Annual income (million) & 0.0051 & 0.0014 & $* * *$ & 0.0009 & 0.0010 & -0.0061 & 0.0016 & $* * *$ \\
\hline Detached house owner & 0.0333 & 0.0170 & $* *$ & 0.0059 & 0.0104 & -0.0392 & 0.0196 & $* *$ \\
\hline Employed (household head) & -0.0782 & 0.0276 & $* * *$ & -0.0140 & 0.0179 & 0.0922 & 0.0317 & $* * *$ \\
\hline \multicolumn{9}{|c|}{ Educational attainment (household head) } \\
\hline Junior high school & -0.1103 & 0.0287 & $* * *$ & -0.0197 & 0.0200 & 0.1300 & 0.0322 & $* * *$ \\
\hline Junior college & 0.0020 & 0.0254 & & 0.0004 & 0.0147 & -0.0024 & 0.0296 & \\
\hline University / Grad school & 0.1317 & 0.0177 & $* * *$ & 0.0236 & 0.0174 & -0.1552 & 0.0191 & $* * *$ \\
\hline Total financial asset (million) & 0.0004 & 0.0001 & $* * *$ & 0.0001 & 0.0001 & -0.0005 & 0.0001 & $* * *$ \\
\hline
\end{tabular}

Number of observations $=2351$

McFadden's pseudo $\mathrm{R}^{2}=0.091$

Notes: See Table 5(a). 
Table 6(a): Determinants of bank switching behavior (1996)

\begin{tabular}{|c|c|c|c|c|c|c|c|c|}
\hline & \multicolumn{2}{|c|}{ Actually switched } & \multicolumn{3}{|c|}{ Considering to switch } & \multicolumn{3}{|c|}{$\begin{array}{l}\text { Not considering it necessary to } \\
\text { switch }\end{array}$} \\
\hline & $\begin{array}{c}\text { Marginal } \\
\text { effect }\end{array}$ & Std. error & $\begin{array}{c}\text { Marginal } \\
\text { effect }\end{array}$ & Std. error & & $\begin{array}{c}\text { Marginal } \\
\text { effect }\end{array}$ & Std. error & \\
\hline Age (household head) & 0.0023 & 0.0023 & 0.0033 & 0.0028 & & -0.0057 & 0.0049 & \\
\hline $\mathrm{Age}^{2}$ & 0.0000 & 0.0000 & 0.0000 & 0.0000 & & 0.0000 & 0.0001 & \\
\hline Household annual income (million yen) & -0.0006 & 0.0008 & -0.0008 & 0.0010 & & 0.0014 & 0.0017 & \\
\hline Detached house owner & 0.0012 & 0.0016 & 0.0017 & 0.0020 & & -0.0029 & 0.0035 & \\
\hline Employed (household head) & -0.0002 & 0.0113 & -0.0003 & 0.0143 & & 0.0006 & 0.0250 & \\
\hline \multicolumn{9}{|l|}{ Educational attainment (household head) } \\
\hline Junior high school & 0.0079 & 0.0110 & 0.0112 & 0.0135 & & -0.0190 & 0.0239 & \\
\hline Junior college & 0.0131 & 0.0110 & 0.0186 & 0.0131 & & -0.0317 & 0.0233 & \\
\hline University / Grad school & 0.0043 & 0.0070 & 0.0061 & 0.0086 & & -0.0104 & 0.0153 & \\
\hline Financial assets (million yen) & 0.0005 & $0.0002 * *$ & 0.0007 & 0.0002 & $* * *$ & -0.0012 & 0.0005 & $* * *$ \\
\hline Ordinary deposits $>=10$ million yen & -0.0967 & 0.0869 & -0.1372 & 0.1051 & & 0.2339 & 0.1859 & \\
\hline Time deposits $>=10$ million yen & 0.0125 & 0.0114 & 0.0178 & 0.0135 & & -0.0303 & 0.0241 & \\
\hline \multicolumn{9}{|l|}{ Knowledge of the deposit insurance scheme } \\
\hline Knowledge $=2$ (detailed knowledge $)$ & 0.0048 & 0.0117 & 0.0068 & 0.0147 & & -0.0115 & 0.0258 & \\
\hline Knowledge $=0$ (no knowledge $)$ & -0.0110 & 0.0073 & -0.0155 & 0.0083 & $*$ & 0.0265 & 0.0150 & $*$ \\
\hline \multicolumn{9}{|c|}{ The most important reason for choosing a financial institution } \\
\hline $\begin{array}{l}\text { Location, number and opening hours } \\
\text { of branches }\end{array}$ & -0.0112 & 0.0087 & -0.0159 & 0.0102 & & 0.0271 & 0.0183 & \\
\hline Service contents & -0.0048 & 0.0093 & -0.0067 & 0.0116 & & 0.0115 & 0.0204 & \\
\hline Financial condition & 0.0056 & 0.0089 & 0.0079 & 0.0111 & & -0.0135 & 0.0195 & \\
\hline \multicolumn{9}{|l|}{ Number of observations $=2445$} \\
\hline McFadden's pseudo $\mathrm{R}^{2}=0.041$ & & & & & & & & \\
\hline
\end{tabular}

Note: 1 . We employed an order probit model. ***,** and * denote that the null hypothesis that the estimated marginal effect is equal to zero is rejected at the 1,5 and $10 \%$ level of significance, respectively.

2. The base case for educational attainment is "high school" and that for area of residence is central Tokyo (23 wards). The coefficients on the area of residence were insignificant and are omitted from this table to conserve space. The base case for the most important reason for choosing a particular financial institutions is "interest rate." 
Table 6(b): Determinants of bank switching behavior (2001)

\begin{tabular}{|c|c|c|c|c|c|c|c|c|}
\hline & \multicolumn{3}{|c|}{ Actually switched } & \multicolumn{2}{|c|}{ Considering to switch } & \multicolumn{3}{|c|}{$\begin{array}{l}\text { Not considering it necessary } \\
\text { to switch }\end{array}$} \\
\hline & $\begin{array}{l}\text { Marginal } \\
\text { effect }\end{array}$ & Std. error & & $\begin{array}{l}\text { Marginal } \\
\text { effect }\end{array}$ & Std. error & $\begin{array}{l}\text { Marginal } \\
\text { effect }\end{array}$ & Std. error & \\
\hline Age (household head) & 0.0013 & 0.0022 & & 0.0038 & 0.0053 & -0.0050 & 0.0066 & \\
\hline $\operatorname{Age}^{2}$ & 0.0000 & 0.0000 & & 0.0000 & 0.0001 & 0.0001 & 0.0001 & \\
\hline Detached house owner & 0.0007 & 0.0098 & & 0.0020 & 0.0239 & -0.0026 & 0.0297 & \\
\hline Employed (household head) & -0.0086 & 0.0118 & & -0.0256 & 0.0287 & 0.0342 & 0.0356 & \\
\hline \multicolumn{9}{|l|}{ Educational attainment (household head) } \\
\hline Junior high school & -0.0068 & 0.0153 & & -0.0202 & 0.0374 & 0.0269 & 0.0464 & \\
\hline Junior college & 0.0083 & 0.0139 & & 0.0246 & 0.0336 & -0.0329 & 0.0418 & \\
\hline Time deposits $>=10$ million yen & 0.0511 & 0.0182 & $* * *$ & 0.1518 & $0.0352 * * *$ & -0.2029 & 0.0399 & $* * *$ \\
\hline \multicolumn{9}{|c|}{ Knowledge regarding the reinstatement of the deposit insurance cap } \\
\hline Knowledge $=2$ (detailed knowledge) & 0.0112 & 0.0086 & & 0.0331 & 0.0204 & -0.0443 & 0.0250 & $*$ \\
\hline Knowledge = 0 (no knowledge) & -0.0134 & 0.0112 & & -0.0397 & 0.0262 & 0.0530 & 0.0325 & \\
\hline \multicolumn{9}{|c|}{ The most important reason for choosing a financial institution } \\
\hline Lower fees & 0.0091 & 0.0105 & & 0.0269 & 0.0253 & -0.0360 & 0.0314 & \\
\hline $\begin{array}{l}\text { Location, number and opening hours } \\
\text { of branches }\end{array}$ & 0.0018 & 0.0098 & & 0.0052 & 0.0239 & -0.0070 & 0.0297 & \\
\hline Service contents & 0.0081 & 0.0096 & & 0.0241 & 0.0232 & -0.0322 & 0.0288 & \\
\hline \multicolumn{9}{|l|}{ Number of observations $=1756$} \\
\hline
\end{tabular}

Notes: See Table 6(a). 